\title{
Genetic Variability Study Among Ten Cultivars of Cowpea (Vigna unguiculata L. Walp) Using Morpho-agronomic Traits and Nutritional Composition
}

\author{
D. A. Animasaun ${ }^{1}$, S. Oyedeji ${ }^{1}$, Y. K. Azeez ${ }^{1}$, O. T. Mustapha ${ }^{1}$ and M. A. Azeez ${ }^{2}$
}

Received: $16^{\text {th }}$ October, $2014 /$ Accepted : 07 $7^{\text {th }}$ March, 2015

\begin{abstract}
Ten cultivarsof cowpea grown in the screen house facility at Botanical garden, University of Ilorin, Nigeriawereevaluated for genetic similarity and variability. Data were collected on vegetative, fruiting and seed characters. Proximate analysis was conducted to determine variation in nutrient composition of the seeds at harvest. The results showed considerable variations in growth and yield characters evaluated. Cultivars NGB/06/047, IFE BROWN 2012 and IT98K-133-1-1 had optimal growth performance with respect to fruiting and seed yield parameters. Proximate results indicated thatcrude protein varied from 23.42-26.78\%. Ash content ranged between 3.60-4.21\%, crude fibre varied from 2.10-2.98\%, and carbohydrates56.10-59.59\%. Principal components analysis revealed that first principal components (majorly fruiting and seed characters) accounted for $26.63 \%$ observed variation, followed by the second component (23.05\%) which are mainly vegetative parameterswhile third (13.82\%) consisting of nutritional variations. The cultivars were dividedinto two broad genetic groups $(A \& B)$. Group A consist of two clusters which members showed low performance in terms of economic traits and group $B$ comprised two clusters of superior cultivarsfor most of the traits studied. Variability as expressed in the studied cultivars could be useful for understanding genetic diversity of selection of cultivars with novelty in vegetative growth, yield and nutrition composition in the process of breeding programme and crop production.
\end{abstract}

Key words: Agronomic traits, proximate analysis, variability, Vigna unguiculata

\section{INTRODUCTION}

One of the major global challenges of the millennium is food security and how to address the phenomenon of malnutrition among the teeming and ever rising population of poor rural dwellers of the third world countries. In the wake of climate changes, fluctuating global economy and intensification of low-input agricultural production which has led to a rapid increase in soil degradation and nutrient depletion in many parts of sub-Saharan Africa, constituting serious threats to food production and food security, there is need to promote crops that could fix into global nutrient requirements. One of such crop is cowpea.

Cowpea (Vigna unguiculata) has the largest usable protein content of all cultivated legumes and is arguably one of the most important plant protein source as a valuable and dependable commodity crop for farmer and grain traders (Nwosu et al., 2013). With an annual worldwide estimated production of about 4.5 million metric tons, cowpea provides food for several millions of people in developing world (FAO, 2004: Diouf, 2011). Cowpea is grown mostly by poor farmers in the developing countries with over $80 \%$ of the production coming from the savannas of tropical Africa. Nigeria and Niger accounts for about two-third of the world's production (Mortimore et al., 1997; Ortiz, 1998). In the past decades though, advances in crop development have opened opportunities for its production in wet agro-ecologies (Nwofiae t al., 2012).

As a legume grain, cowpea is an important source of human dietary protein and calories.

\footnotetext{
Department of Plant Biology, Faculty of Life Sciences, University of Ilorin, P. M. B. 1515, Ilorin, Kwara State, Nigeria

Department of Pure and Applied Biology, LadokeAkintola University of Technology, Ogbomosho, Oyo State, Nigeria
} 
The grains contain about $25 \%$ proteins and $64 \%$ carbohydrate, while young leaves, pods and peas contain vitamins and minerals (Nielsen et al, 1997). Its high protein and lysine content makes it natural supplement for high carbohydrates tubers and cereals which are common staple foods among the Sub-Saharan people. According to Geissler et al., (1998), malnutrition among the children in developing countries is mainly due to the consumption of cereal based meal which is bulky, high energy and anti-nutrients. Therefore, cowpea provides protein constituent of the daily diet of the economically depressed rural class, due to its potential to reduce malnutrition; it is sometimes being referred to as "poor man's meat" (Geissler et al., 1998). Its utilization is majorly as grain crop, vegetables and fodder for livestock (Hall et al., 2003).

Cowpea production is faced with a number of constraints which are biotic and abiotic that resulted into low grain and fodder yield. In most West African countries, development and release of improved varieties that adapts well and yield better have been slow in getting to the farmers (FAO, 2000). Development of cultivars with early maturity, acceptable grain quality, resistance to diseases and pests is necessary to overcome the ever growing food shortage (Ehlers and Hall, 1997). Hence, there is need to generate more information on variability among the existing germplasm and cultivars and also broadening the gene pool of the crop for selection and development of more improved varieties not just in yield but with better nutritional values.

The study of variability and diversity in accessions of cultivated crops could provide vital information for the establishment of breeding programme, especially when intraspecific hybridization are necessary for the incorporation of new features or for mapping purposes. Assessment of genetic diversity and variability in cowpea would enhance development of cultivars for adaptation to specific production constrain. Therefore, sufficient information is necessary on genetic variability among the available germplasm to formulate and accelerate breeding programme. Previous workers have reported on genetic variability among different varieties of cowpea (Omoigu et al,. 2006; Nwosu et al., 2013) and a number of reports on the nutrient analysis (Henshaw, 2008; Mamiro et al., 2011; Odedeji and Oyeleke, 2011). However, only few of these reports compared nutrient composition of different varieties and in particular the early maturing varieties.

In order to achieve a successful breeding programme to improve the yield potentials of the crop, the quality of the grains in term of its nutritional values should also be a pivot concern. This enables the breeder to operate selection efficiently and subsequently developed appropriate breeding strategies to solve the problems of poor yield as well as improve the nutritive quality of the crop. To this end, this study evaluates variability that exists for different agronomic characters and nutritional compositions among cowpea varieties from selected Research Institutes in Nigeria with a view to classify these cultivars according to the variations in those characteristics. Effort was made to examine the genetic differences among the studied cultivars to group them into relatively homogenous groups of baseline parents for breeding purposes.

\section{MATERIALS AND METHODS}

\section{Seed Collection}

Seeds of ten cultivars of cowpea collected from three different Research Institutes that were involved in conservation of cowpea germplasm in Nigeriawere used for the study. The institutes are; National Centre for Genetic Resources and Biotechnology (NACGRAB), Nigeria Agricultural Quarantine Services (NAQS), and International Institute for Tropical Agriculture (IITA) all located in Ibadan, Oyo State, Nigeria (Table 01). 
Table 01: Accession name and sources of ten early maturing cultivarsof Vigna unguiculata evaluated for agronomic and nutrient variability.

\begin{tabular}{lll}
\hline VARIETIES FROM NAQS & VARIETIES FROM NACGRAB & VARIETIES FROM IITA \\
\hline IT99K-1060 & IFE BROWN & IT06K-128 \\
IT07K-243-1-10 & NGB/SA/JAN/09/011 & IT98K-133-1-1
\end{tabular}

IT07K-187-24 NGB/06/047

IFE BROWN 2012

IT77K-1042-3

NACGRAB: National Centre for Genetic Resources and Biotechnology, Moor Plantation, Ibadan, Oyo State, Nigeria

NAQS: $\quad$ Nigeria Agricultural Quarantine Services, Moor Plantation, Ibadan, Oyo State, Nigeria

IITA: International Institute for Tropical Agriculture, Oyo Road, Ibadan, Oyo State, Nigeria

The experiment was conducted in a screen house facility in the Botanical garden, University of Ilorin (N $08^{0} 28^{\prime} 53.3$ ", E 040 40' 28.9"), Ilorin, Nigeria. Ilorin lies within the transition zone between the humid and semi humid tropic zone. It is majorly woodland savannah with bimodal rainfall (about $1200 \mathrm{~mm} /$ annum) distribution with peaks in June and early September, usually separated by a period of lower precipitation in August. Temperature varies between $33^{\circ} \mathrm{C}$ and $34^{\circ} \mathrm{C}$ with November to April constituting the major dry season in this area (Olaniran, 1982).

\section{Germination studies}

The germination test was carried out in the Plant Biology Laboratory, University of Ilorin. Ten seeds of each cultivars were plated in a plastic lunch-box laid with damp filter papers and set up in triplicates. Observation was made daily until the tenth day after sowing when maximum number of seeds had germinated. Mean percentage germination was determined for each of the cultivars.

\section{Morphological evaluation}

Two plants were raised in polythene planting bag $(36 \mathrm{~cm}$ x $30 \mathrm{~cm})$ filled with sandy loam soil for each cultivar. The experiment was set up in a randomized complete block design with five replicates, spacing of $50 \mathrm{~cm}$ between plants and $60 \mathrm{~cm}$ between the rows. Management practices were followed in time as required. Data were collected on five randomly selected plants for plant height, number of leaves and other vegetative agronomic yield parameters. At maturity, number of day to flowering, days to maturity, number of pods/plant, pod length, number of seed/pod and weight of 100 seeds were evaluated. Qualitative characters considered in this study are plant growth pattern, flower colour, seed shape (classified according to Ogle et al.,1987), seed coat colour, seed coat texture and the helium eye colour.

\section{Proximate analysis}

Proximate analysis for the seeds was carried out to determine the moisture content, crude proteins, crude lipids, fibre content, ash and carbohydrate proportions in the seed according to the standard method of AOAC (1995). The total carbohydrate present in the seed was obtained by the difference. Percentage dry matter (moisture) was determined by drying the nuts in an oven at $103^{\circ} \mathrm{C}-105^{\circ} \mathrm{C}$ for 24 hours and the amount of moisture was determined based on standard method of AOAC (1995). MicroKjeldahl method was employed to determine the total nitrogen and crude protein ( $\mathrm{N} x$ 5.95). Crude lipids were extracted with petroleum ether using Soxhlet apparatus HT-extraction technique, percentage ash (\% minerals) and 
crude fibre percentage was determined based on published method of Olaleke et al. (2006). Total carbohydrate was estimated by difference method.

\section{Data analysis}

The collected data were subjected to analysis of variance (ANOVA) using SPSS 17.0 for Windows Computer Software Package. Standardized traits mean values were used to perform principal components and hierarchical cluster analyses. Cluster analysis based on squared Euclidean distances as similarity measures and Ward's method were used to analyze genetic relationships among the accessions.

\section{RESULTS AND DISCUSION}

Germination occurred in some of the varieties three days after sowing (DAS) with highest number of germination observed in NGB/SA/ JAN/09/11 and IT98K-133-1-1 where about 60\% of the seeds germinated while $50 \%$ germination was achieved in IT07K-243-1-10, IFE BROWN 2012 and IT99K-1060 at 3DAS. About $80 \%$ of the seeds germinated on the fourth day, though a few on the fifth day. However, germination was slow in NGB/06/047 and IT07K-187-24 which did not germination until 5DAS (Figure 01). The low percent germination in Ife Brown, NGB/06/047 and IT07K-187-24 suggests they might have immature or non-viable embryo.

At two weeks after sowing (2WAS), growth was rapid in IT07K-243-10 and IT98K-133-1-1 with mean plant height of 24.96 and $20.66 \mathrm{~cm}$ respectively. Variations were observed with respect to plant height, leaf length, number of leaves and other growth parameters evaluated (Table 02). Plant height was not in direct proportion to number of leaves and other foliage characteristics. A similar result was reported by Lesley (2005), who observed variations in plant height, stem girth and other vegetative characters among the accession of cowpea he studied. At six weeks after sowing (6WAS), IT07K-243-10 had the best performances for all parameters evaluated except in the number of leaves and branches (Figure 02). Average plant height was highest in IT07K-243-10 (68.54 $\mathrm{cm})$ and IT98K-133-1-1 (64.40 cm) while IFE BROWN was at the far rear $(20.26 \mathrm{~cm})$.With respect to leaf length and breath, IT06K-128 showed best performance while the least mean leaf dimension was recorded among NGB/ SA/JAN/09. More also, number of leaves per plant was diverse among the assessed cultivars; highest number of leaves was recorded among IT77K-1042-3 (average of 13 leaves per plant) which also is the most branched cultivar.

In all the parameters considered at 6WAS, IFE BROWN produced the least performance except in leaf length which was higher than at least two other cultivars (Fig 02). The observed variability was in agreement with the workof Nwosu et al., (2013)and could serve important purpose in improving the crop as selection would be effective for population with broad genetic variability as opined by previous workers(Omoigui et al., 2006; Dento and Nwangburuka, 2011). The vegetative growth at maturity was similar to 6WAS, generally, Ife Brown and IT77K187-24 showed considerable reduction in vegetative growth in comparison to other cultivars (Table 03). The climbing cultivars had greater plant height than semi erect and erect. Thus considering the plant height, IT98K-133-1-1, IT07K-243-10, IT99K-1060 and Ife Brown 2012 showed greater plant height than others. The low or high performance of the studied cultivars may not depend on genetic factor alone but also on environmental influences as earlier elucidated (Umaharanet al., 1997; Manggoel et al., 2012; Nwosu et al., 2013). 


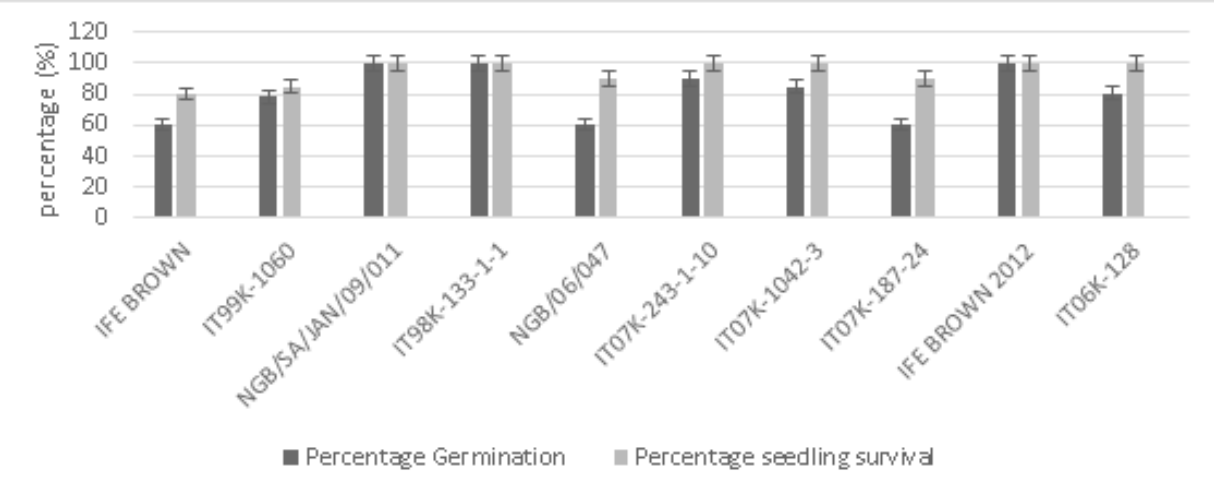

Figure 01: Percentage germination at $6^{\text {th }}$ day after sowing and percentage seedling survival of $V$. unguiculatacultivars

Table 02: Vegetative growth of ten cultivars of $V$. unguiculata 2 Weeks after sowing (2WAS)

\begin{tabular}{lccccc}
\hline Accessions & $\begin{array}{c}\text { Plant Height } \\
(\mathrm{cm})\end{array}$ & $\begin{array}{c}\text { Leaf Length } \\
(\mathrm{cm})\end{array}$ & $\begin{array}{c}\text { Leaf Breadth } \\
(\mathrm{cm})\end{array}$ & $\begin{array}{c}\text { Stem girth } \\
(\mathrm{cm})\end{array}$ & $\begin{array}{c}\text { Number of } \\
\text { Leaves }\end{array}$ \\
\hline IFE BROWN & $10.84 \pm 1.20$ & $2.56 \pm 0.61$ & $1.36 \pm 0.45$ & $0.38 \pm 0.06$ & $2.00 \pm 0.81$ \\
IT99K-1060 & $11.86 \pm 1.03$ & $2.400 \pm 0.45$ & $1.36 \pm 0.12$ & $0.31 \pm 0.03$ & $6.60 \pm 2.20$ \\
NGB/SA/JAN/09 & $10.90 \pm 2.00$ & $2.36 \pm 0.68$ & $1.22 \pm 0.24$ & $0.39 \pm 0.08$ & $4.40 \pm 1.73$ \\
IT98K-133-1-1 & $20.66 \pm 3.98$ & $3.48 \pm 0.98$ & $1.86 \pm 0.41$ & $0.44 \pm 0.07$ & $3.80 \pm 0.97$ \\
NGB/06/047 & $11.46 \pm 2.95$ & $2.44 \pm 0.46$ & $1.48 \pm 0.56$ & $0.37 \pm 0.07$ & $5.60 \pm 2.01$ \\
IT07K-243-10 & $24.96 \pm 3.91$ & $4.44 \pm 0.97$ & $2.48 \pm 0.54$ & $0.41 \pm 0.06$ & $5.20 \pm 1.97$ \\
IT77K-1042-3 & $11.76 \pm 2.41$ & $3.60 \pm 0.48$ & $1.88 \pm 0.32$ & $0.48 \pm 0.06$ & 6.802 .04 \\
IT77K187-24 & $17.58 \pm 3.02$ & $3.90 \pm 0.78$ & $2.08 \pm 0.53$ & $0.38 \pm 0.04$ & $3.80 \pm 0.87$ \\
IFE BROWN 2012 & $17.34 \pm 3.21$ & $3.48 \pm 0.82$ & $1.84 \pm 0.38$ & 0.410 .03 & $4.602 \pm 1.45$ \\
IT06K-128 & $12.52 \pm 2.97$ & $5.38 \pm 0.65$ & $2.66 \pm 0.24$ & $0.48 \pm 0.06$ & $3.20 \pm 0.96$ \\
\hline
\end{tabular}

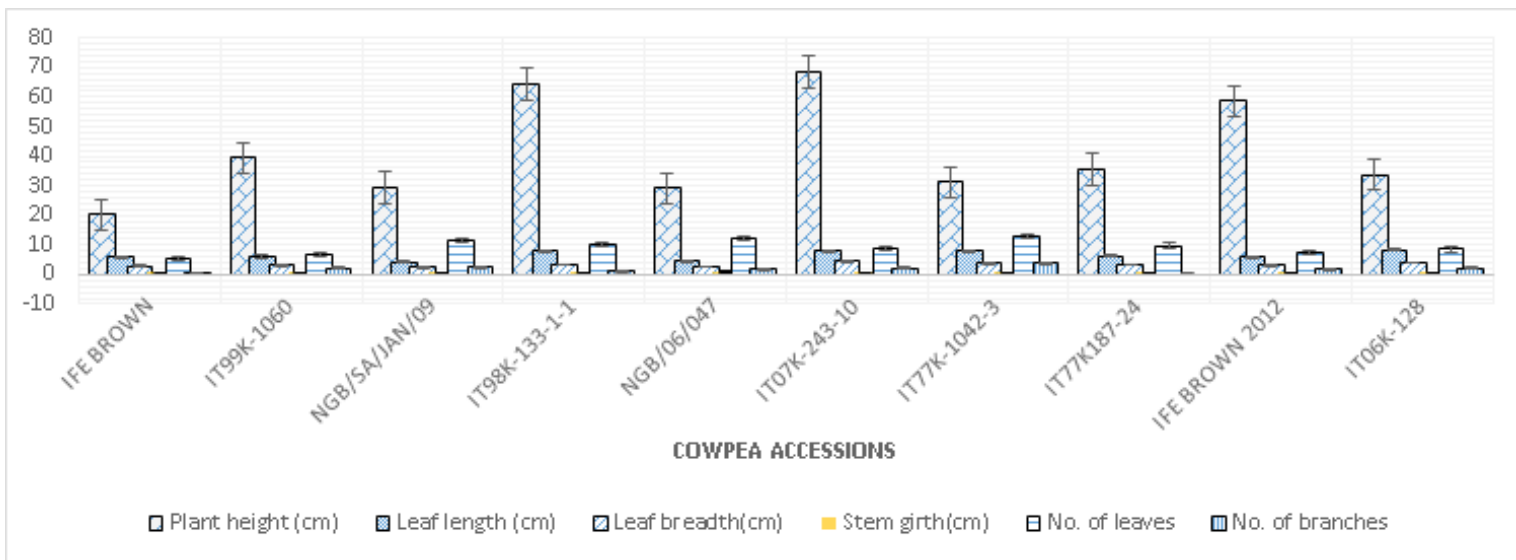

Figure 02: Variation in vegetative growth characteristic of ten cultivars of $V$. unguiculata at six weeks after sowing 
Table 03: Showing variations in characters of ten cultivars of $V$. unguiculata evaluated at maturity

\begin{tabular}{lcccccccc}
\hline \multicolumn{1}{c}{ Var. } & $\begin{array}{c}\text { PH } \\
(\mathrm{cm})\end{array}$ & NL & $\begin{array}{c}\text { LL } \\
(\mathrm{cm})\end{array}$ & $\begin{array}{c}\text { LB } \\
(\mathrm{cm})\end{array}$ & $\begin{array}{c}\text { SG } \\
(\mathrm{cm})\end{array}$ & NB & NDF & $\begin{array}{c}\text { NDF } \\
(50 \%)\end{array}$ \\
\hline IFE BROWN & $40.52 \pm 4.20$ & $6.80 \pm 2.10$ & $6.54 \pm 1.34$ & $2.98 \pm 0.10$ & $0.87 \pm 0.92$ & $0.97 \pm 0.10$ & $52.48 \pm 5.77$ & $58.10 \pm 6.01$ \\
IT99K-1060 & $41.86 \pm 4.11$ & $9.60 \pm 2.76$ & $6.62 \pm 1.98$ & $3.27 \pm 0.60$ & $0.99 \pm 0.34$ & $2.20 \pm 0.67$ & $49.72 \pm 5.33$ & $56.30 \pm 6.22$ \\
NGB/SA/JAN/09 & $45.11 \pm 6.23$ & $12.92 \pm 3.01$ & $4.72 \pm 1.56$ & $2.56 \pm 0.90$ & $0.92 \pm 0.02$ & $2.86 \pm 0.49$ & $44.24 \pm 4.32$ & $49.41 \pm 5.23$ \\
IT98K-133-1-1 & $76.98 \pm 8.03$ & $15.16 \pm 4.21$ & $7.99 \pm 2.01$ & $3.42 \pm 0.76$ & $1.04 \pm 0.97$ & $1.48 \pm 0.77$ & $38.32 \pm 4.45$ & $41.48 \pm 5.61$ \\
NGB/06/047 & $35.95 \pm 3.06$ & $12.52 \pm 3.42$ & $5.46 \pm 1.56$ & $2.87 \pm 0.80$ & $0.98 \pm 0.43$ & $2.04 \pm 0.42$ & $42.56 \pm 5.41$ & $50.10 \pm 4.80$ \\
IT07K-243-10 & $79.00 \pm 4.90$ & $13.80 \pm 4.07$ & $8.70 \pm 3.31$ & $4.92 \pm 1.30$ & $1.01 \pm 0.09$ & $2.06 \pm 0.13$ & $40.17 \pm 4.65$ & $45.60 \pm 6.33$ \\
IT77K-1042-3 & $46.73 \pm 4.80$ & $13.96 \pm 3.03$ & $8.14 \pm 2.45$ & $3.93 \pm 0.98$ & $0.91 \pm 0.92$ & $4.12 \pm 0.99$ & $47.20 \pm 7.21$ & $49.03 \pm 4.56$ \\
IT77K187-24 & $42.42 \pm 4.00$ & $11.60 \pm 3.12$ & $7.19 \pm 2.30$ & $3.61 \pm 0.87$ & $0.89 \pm 0.85$ & $0.00 \pm 0.00$ & $41.34 \pm 6.13$ & $45.00 \pm 6.01$ \\
IFE BROWN 2012 & $68.59 \pm 6.93$ & $12.68 \pm 4.26$ & $6.74 \pm 2.00$ & $3.25 \pm 1.01$ & $0.99 \pm 0.79$ & $1.89 \pm 0.14$ & $37.54 \pm 5.14$ & $40.81 \pm 5.10$ \\
IT06K-128 & $48.82 \pm 3.89$ & $9.28 \pm 2.41$ & $7.14 \pm 2.40$ & $4.06 \pm 1.08$ & $0.86 \pm 0.82$ & $2.19 \pm 0.98$ & $49.25 \pm 4.63$ & $55.41 \pm 6.11$ \\
\hline
\end{tabular}

Key: $\mathrm{PH}=$ Plant Height $(\mathrm{cm}), \mathrm{NL}=$ Number of Leaves, $\mathrm{LL}=$ Leaf Length $(\mathrm{cm}), \mathrm{LB}=$ Leaf Breath $(\mathrm{cm}), \mathrm{SG}=$ Stem girth $(\mathrm{cm})$, $\mathrm{NB}=$ Number of Branches. NDF $=$ Number of Days to Flowering, ND (50\%) = Number of Days to $50 \%$ Flowering.

Flowering commenced 37 days among IFE BROWN 2012; which also attained 50\% ahead of other cultivars. Days to flowering and days to attain 50\% flowering varied for the cultivars as presented in Table 03.Flowering, podding and other seed parameters did not follow the trend of the vegetative growth. Highest number offlowers (29.60) was obtained among NGB/06/047 plants which also produced the highest number of seeds per plant. IT07K-243-1-10 and IFE BROWN 2012 produced average of 28.80 and 27.20 flowers respectively (Table 04). However, IFE BROWN produced more seeds/plant (213.85) than IT07K-243-1-10 (146.30). The results revealed that there was considerable variability in the cultivars with respect to fruiting and seed characters. Zevari et al., (1983)drew similar inference from various traits in accessions they studied. The present finding also corroborated the report of Vural and Karasu, 2007 who reported wide variability in flowering and fruiting characteristicin the verities of cowpea grown in Isparta, Turkey. The number of pod per plant varied among the evaluated cultivars, the variations are in agreement with the findings of Duke, (1980) which showed that pod length varies among the varieties he evaluated. IFE BROWN- $2012(14.12 \mathrm{~cm})$ only came behind IT98K-33-1-1 in term of pod length while IT06K-128 produced shortest mean pod length
$(7.82 \mathrm{~cm})$.Variability in days to flowering, pod dimension and seed yield has been indicated as cardinal to possibilities for the improvement of the cultivars through selection (Selvam et al., 2000; Lesley, 2005).

Growth habit and qualitative seed morphological characteristics of the studied cultivars are shown in Table 05. Growth habit, seed colour, seed shape and seed coat texture are qualitative traits of interest to breeders, so variability in such would enhance cowpea improvement. Erect plants are less susceptible to rodent attack and could also allow the use of mechanical harvesters.

Table 06 showed proximate compositions for the seed of the cultivars. The resultsshowed moisture content ranged between 8.20 and $10.10 \%$, with IT06K-128 having highest moisture (10.21\%) and closely followed by IT77K1042-3 (10.1\%) while IFEBROWN 2012 contained least moisture of $9.02 \%$. Crude protein varied from 23.42 to $26.78 \%$ with highest protein recorded in IFE BROWN 2012 (26.78\%). The cultivar IFE BROWN 2012 with minimum moisture content also had the highest crude protein composition.Mamiro et al.(2011) had reported similar values for crude protein among the local and improved varieties of cowpeagrown 
in some regions of Tanzaia and these values for protein contents are in agreement with the findings of Odedeji and Oyeleke (2011). From the results (Table 06), fats and oil content was similar for all the cultivars except IT99K-1060 with remarkable low fat $(1.98 \%)$. The fat content in the resent study did not agree with values reported by Mamiro et al., (2011)but in agreement with Odedeji and Oyeleke (2011). Ash content ranged between 3.60 to $4.21 \%$, crude fibre varied from 2.10 to $2.98 \%$, while carbohydrates content was between 56.10 and $59.59 \%$ (Table 06 ). The range of carbohydrate content obtained in this study tallied with the values reported by other workers (Olaleke et al., 2006; Mamiro et al., 2011; Odedeji and Oyeleke 2011). Considerable variability exists in the nutritional contents of the cultivars evaluated and this suggests that selection could be made for cultivar with improved nutritional values.

Table 04: Fruit characters evaluated at maturity for ten cultivars of $V$. unguiculata

\begin{tabular}{lrrrrrrrrrrrr}
\hline & & & & & & & & & & & & \\
Var. & NF/P & NDM & PC/P & P/C & P/P & $\begin{array}{c}\text { PL } \\
(\mathrm{cm})\end{array}$ & $\begin{array}{r}\text { PDL } \\
(\mathrm{cm})\end{array}$ & $\begin{array}{l}\text { PB } \\
(\mathrm{cm})\end{array}$ & NSP & SPP & $\begin{array}{c}\text { DPW } \\
(\mathrm{g})\end{array}$ & $\begin{array}{c}100-S W \\
(\mathrm{~g})\end{array}$ \\
\hline 1 & 10.23 & 80.20 & 4.87 & 1.81 & 7.420 & 8.30 & 10.43 & 0.77 & 6.42 & 47.43 & 1.89 & 16.88 \\
2 & 19.80 & 68.20 & 7.32 & 1.60 & 10.76 & 11.41 & 11.01 & 0.72 & 7.60 & 76.41 & 1.78 & 16.46 \\
3 & 23.00 & 68.64 & 11.84 & 1.72 & 11.68 & 9.78 & 12.06 & 0.66 & 10.45 & 112.48 & 1.54 & 14.48 \\
4 & 19.40 & 62.20 & 11.60 & 1.45 & 13.16 & 14.34 & 18.86 & 0.82 & 11.34 & 149.23 & 1.91 & 15.92 \\
5 & 29.60 & 63.82 & 14.81 & 1.92 & 20.80 & 11.56 & 12.16 & 0.71 & 10.45 & 218.41 & 1.86 & 15.45 \\
6 & 28.80 & 78.40 & 9.20 & 1.20 & 9.28 & 13.43 & 10.49 & 0.64 & 7.67 & 146.30 & 1.83 & 16.87 \\
7 & 17.00 & 68.56 & 9.40 & 1.24 & 10.36 & 7.65 & 9.62 & 0.79 & 6.98 & 70.03 & 1.54 & 15.80 \\
8 & 17.40 & 72.30 & 7.10 & 1.55 & 8.92 & 11.08 & 10.82 & 0.63 & 8.76 & 66.34 & 1.88 & 14.36 \\
9 & 27.20 & 59.9 & 12.56 & 1.90 & 19.03 & 13.11 & 14.12 & 0.81 & 11.89 & 213.85 & 1.79 & 17.81 \\
10 & 26.00 & 74.30 & 5.32 & 1.20 & 7.68 & 6.42 & 7.82 & 0.74 & 5.51 & 38.42 & 1.89 & 20.37 \\
\hline
\end{tabular}

Key: 1= IFE BROWN, 2 = IT99K-1060, 3 = NGB/SA/JAN/09/011, 4 = IT98K-133-1-1, 5 = NGB/06/047 6 = IT07K-243-1-10, 7 $=$ IT77K-1042-3, $8=$ IT07K-187-24, $9=$ IFE BROWN 2012, $10=$ IT06K-128

$\mathrm{NF} / \mathrm{P}=$ Number of Flowers $/ \mathrm{Plant}, \mathrm{NDM}=$ Number of Days to Maturity, $\mathrm{FC} / \mathrm{P}=$ Flower Clusters/Plant, $\mathrm{PC}=\mathrm{Pod} / \mathrm{Cluster}, \mathrm{P} / \mathrm{P}=\mathrm{Pod}$ /Plant, $\mathrm{PL}=$ Peduncle Length, $\mathrm{PDL}=$ Pod Length, $\mathrm{PB}=$ Pod Breadth, NSP $=$ Number of Seeds $/ \mathrm{Pod}, \mathrm{SPP}=$ Seed per Plant, DPW= Dried Pod Weight, 100-SW = 100-Seed Weight.

Table 05: Qualitative traits variation among ten cultivars of $V$. unguiculata evaluated.

\begin{tabular}{lcccccc}
\hline \multicolumn{1}{c}{ Accessions } & $\begin{array}{c}\text { Growth } \\
\text { habit }\end{array}$ & $\begin{array}{c}\text { Flower } \\
\text { colour }\end{array}$ & Coat Colour & Seed Shape & $\begin{array}{c}\text { Seed/Coat } \\
\text { Texture }\end{array}$ & Hilium Eye \\
\hline IFE BROWN & Erect & White & Light Brown & Rhomboid & Wrinkled & White \\
IT99K-1060 & Crawling & White & Light Brown & Kidney & Smooth & Dark Brown \\
NGB/SA/JAN/09/011 & Semi erect & Purple & White & Kidney & Smooth & White \\
IT98K-133-1-1 & Crawling & White & Maroon & Reniform & Smooth & White \\
NGB/06/047 & Erect & White & White Cream & Kidney & Wrinkled & White \\
IT07K-243-1-10 & Crawling & White & White & Rhomboid & Smooth & Cream \\
IT77K-1042-3 & Erect & Purple & Pink & Kidney & Smooth & White \\
IT07K-187-24 & Semi-erect & Purple & White & Reniform & Smooth & Brown \\
IFE BROWN 2012 & Crawling & White & Light Brown & Rhomboid & Wrinkled & Brown \\
IT06K-128 & Semi-erect & White & White & Kidney & Smooth & Dark brown \\
\hline
\end{tabular}


Table 06: Proximate analysis of the harvested seeds of ten cultivars of $V$. unguiculata

\begin{tabular}{lcccccc}
\hline \multicolumn{1}{c}{ Accessions } & $\begin{array}{c}\text { Moisture } \\
\text { content }(\%)\end{array}$ & $\begin{array}{c}\text { Ash } \\
\text { content } \\
(\%)\end{array}$ & $\begin{array}{c}\text { Fat/oil } \\
\text { content } \\
(\%)\end{array}$ & $\begin{array}{c}\text { Crude fibre } \\
\text { content } \\
(\%)\end{array}$ & $\begin{array}{c}\text { Crude } \\
\text { protein } \\
\text { content }(\%)\end{array}$ & $\begin{array}{c}\text { Carbohydrate } \\
\text { content }(\%)\end{array}$ \\
\hline IFE BROWN & 9.40 & 3.81 & 2.15 & 2.79 & 23.46 & 58.39 \\
IT99K-1060 & 8.52 & 4.02 & 1.98 & 2.98 & 24.60 & 57.90 \\
NGB/SA/JAN/09 & 9.30 & 4.11 & 2.04 & 2.88 & 24.20 & 57.47 \\
IT98K-133-1-1 & 9.37 & 3.78 & 2.08 & 2.97 & 23.18 & 58.62 \\
NGB/06/047 & 8.20 & 3.60 & 2.13 & 2.78 & 24.99 & 58.30 \\
IT07K-243-10 & 9.34 & 3.72 & 2.18 & 2.46 & 25.50 & 56.80 \\
IT77K-1042-3 & 10.10 & 4.10 & 2.09 & 2.38 & 23.42 & 57.91 \\
IT77K187-24 & 9.33 & 4.21 & 2.06 & 2.55 & 22.26 & 59.59 \\
IFE BROWN 2012 & 9.04 & 3.70 & 2.28 & 2.10 & 26.78 & 56.10 \\
IT06K-128 & 10.21 & 3.70 & 2.05 & 2.59 & 23.49 & 57.96 \\
\hline
\end{tabular}

The Principal components analyses for morphoagronomic traits and nutritional components showed that the result could be explained in multi-dimensional spaces (Figure 03). The analysis revealed the first three principal components accounted for approximately $63.49 \%$ of the total variation among the ten cultivars (Table 07). Most of the genetic variation observed was explained by the first principal components (26.63), followed by the second (23.05) and the third (13.82). Seeds per plant (SPP), Peduncle length (PL), Stem girth at maturity (SGM), number ofseeds per pod (NSP) and flower cluster per plant (FC/P) had high positive loadings, while number of days to flowering (NDF) had high negative loading on the first principal components (Table 07).

In the second component, plant traits such as leaf breadth and leaf length at different stages of growth (2WAS, 6WAS and Maturity) had high positive loadings (Table 07). Whereas, the most important variables contributing to the third principal components were: number of leaves (6WAS), number of branches (6WAS), number of branches at maturity (NBM), flower colour (FC), number of leaves (2WAS) with strong positive loadings and dried pod weight (DPW) with high negative loading (Table 07). Vural and Karasu (2007),had indicated that seed and pod size factors contributed the highest percentage of variability observed among the Turkish varieties of cowpea he evaluated for variability. He concluded that similarities and variability among his studied varieties were majorly in the fruiting and seed characters.

The graphic representations of the accessions on principal components 1, 2 and 3 are shown in Figure 03. Here, the spatial distribution of most of the cultivars is very narrow except for four (IT99K-1060 (AC2), NGB/SA/ JAN/09/011 (AC3), IT98K-133-1-1 (AC4) and IT77K-1042-3 (AC7)) which are widely separated. The Dendogram of relationships constructed using Ward's method (Figure 04) grouped the ten cultivars into two broad genetic groups (A and $\mathrm{B}$ ) basedon all the characters on which they were evaluated. Group A was further divided into cluster I consisting of five members such as IT77K-1042-3, IT07K-187-24, IT99K-1060, IFE BROWN and IT06K-128, while cluster II was occupied by single cultivar (NGB/SA/JAN/09/011). Members of this group showed generally low performance in terms of the economic traits except for IT06K-128 that had highest 100-seed weight and moisture content, cultivar IT07K-187-24 which showed highest ash content and IT77K-1042-3 with highest number of branches. 


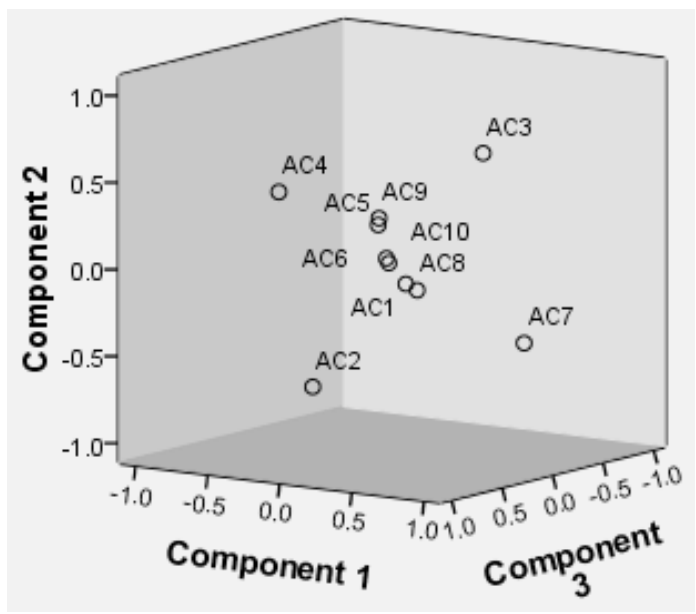

Key: AC1=IFE BROWN, AC2= IT99K-1060, AC3= NGB/SA/JAN/09/011, AC4= IT98K-133-1-1, AC5= NGB/06/047, AC6= IT07K-243-1-10, AC7= IT77K-1042-3, AC8= IT07K-187-24, AC9= IFE BROWN 2012, AC10= IT06K-128.

Figure 03: Graphic representation of the ten accessions of cowpea on the principal components 1,2 and 3

Table 07: Eigen vectors and percentage explained variation by the first three principal components of morpho-agronomic traits and nutritional composition of ten cultivars of Cowpea

\begin{tabular}{lccc}
\hline \multicolumn{1}{c}{ Components } & Prin 1 & Prin 2 & Prin 3 \\
\hline Eigen value variance & 11.453 & 9.909 & 5.940 \\
Individual percentage (\%) & 26.634 & 23.045 & 13.815 \\
Cumulative percentage (\%) & 26.634 & 49.679 & 63.493 \\
Eigenvectors* & SGM $(0.851)$ & LL(2WAS) $(0.903)$ & NL $(6$ WAS) $(0.850)$ \\
& NDF $(-0.871)$ & LB(2WAS) $(0.922)$ & DPW $(-0.809)$ \\
& FC/P $(0.827)$ & LL $(6$ WAS) $(0.911)$ & NBM $(0.773)$ \\
& PL $(0.866)$ & LB $(6$ WAS $)(0.943)$ & NB $(6$ WAS $)(0.798)$ \\
& NSP $(0.849)$ & LLM $(0.866)$ & NL $(2 W A S)(0.646)$ \\
& SPP $(0.948)$ & LBM $(0.934)$ & FC $(0.672)$
\end{tabular}

*Only variables showing high loading in different principal components were taken into consideration

$\mathrm{SGM}=$ Stem girth at matuity, $\mathrm{NDF}=$ Number of days to Flowering, $\mathrm{FC} / \mathrm{P}=$ Flower Clusters $/$ Plant, $\mathrm{PL}=$ Peduncle Length, NSP $=$ Number of Seeds/Pod, SPP $=$ Seed per Plant, LL(2WAS $)=$ Leaf length at 2 weeks after sowing, LB $(2$ WAS $)=$ Leaf breadth 2 weeks after sowing, LL(6WAS) $=$ Leaf length at 6 weeks after sowing, LB(6WAS) $=$ Leaf breadth 6 weeks after sowing, LLW $=$ Leaf length at maturity, LBM $=$ Leaf breadth at maturity, NL(6WAS $)=$ Number of leaves at 6 weeks after sowing, DPW $=$ Dried Pod Weight, $\mathrm{NBM}=$ Number of branches at maturity, NB(6WAS) $=$ Number of branches at 6 week after sowing, NL(2WAS)= Number of leaves at 2 week after sowing.

On the other hand, Members of the Group B are made up of superior cultivars for most of the traits studied. The group was subdivided into cluster I and II consisting two cultivars each such as IT98K-133-1-1 and IT07K-243-1-10 in subcluster I, and NGB/06/047 and IFE BROWN 2012 in subcluster II (Figure 04). IT98K-133-1-1 and IT07K-243-1-10 have crawling habits, produced white flower and smooth seed coat but differed for other qualitative traits, and they showed good performance for plant height, stem girth and pod length (Fig 04). NGB/06/047 and IFE BROWN 2012 also produced white flowers, manifested wrinkled seed coat and differed for other quantitative traits, however, the both manifested highest pod cluster per plant, pod per cluster, pod per plant and seeds per pod at 6-week after sowing (6WAS) 


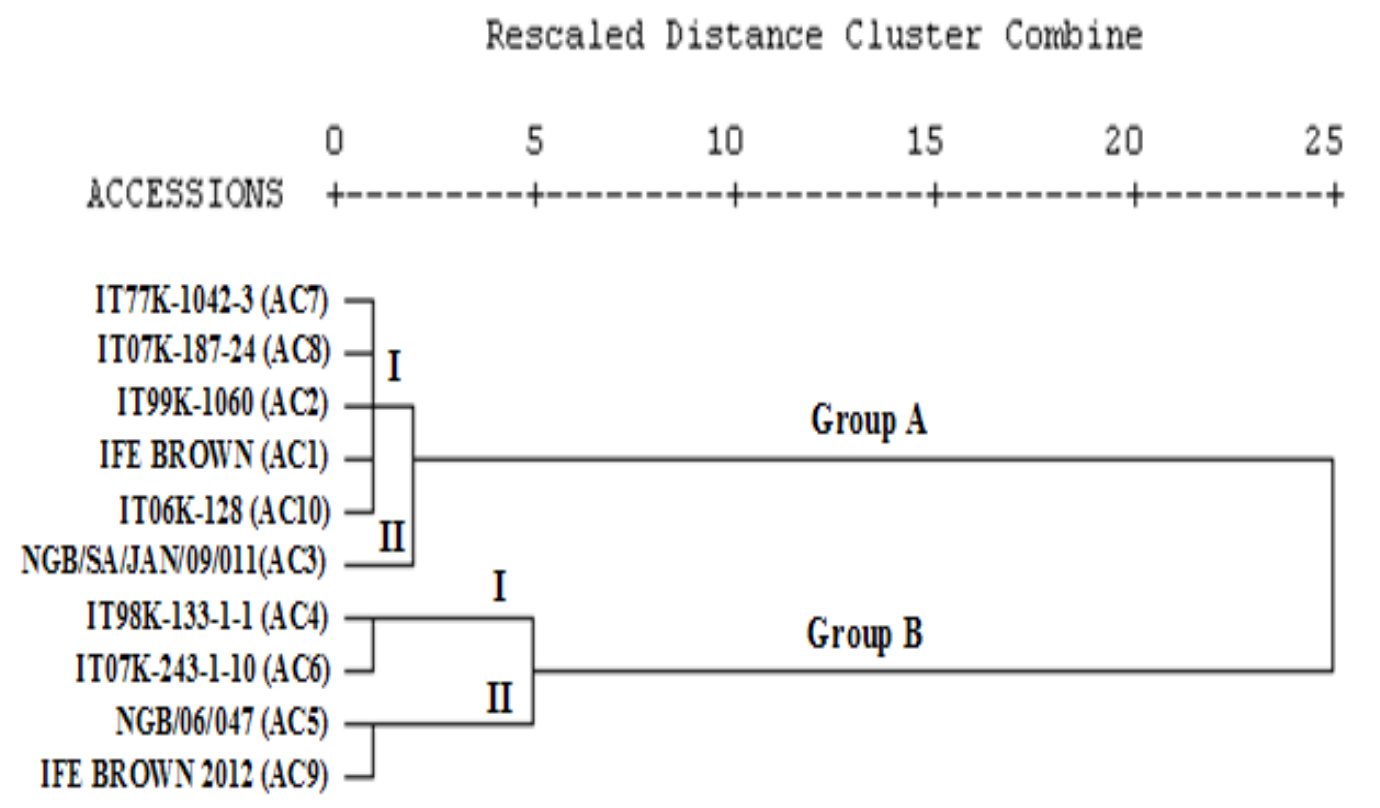

Figure 04: Dendogram of hierarchical clustering of ten accessions of cowpea based on
morpho-agronomic traits and nutritional composition

\section{CONCLUSION}

In this study, the results showed there exist that for optimal yield and higher protein substantial variation in the characters evaluated content, IFE BROWN 2012 and NGB/06/047 to warrant selection of promising genotypes in could be selected for further screening in a term of yield and nutritional values for further breeding programme. The study concludes that improvement. Variations observed in vegetative considerable variability and genetic similarity growth parameters was not in direct relation which were observed among the cultivars to fruiting, seed characteristics and nutrient in vegetative growth, yield and nutrition content which suggest that characters of interest composition may be selected and utilized in should be specifically selected and screened the process of breeding programme and crop for crop improvement.The results revealed production.

\section{REFERENCES}

AOAC (1995).Official methods of analysis. Association of Official Analytical Chemists methods. AOAC $16^{\text {th }}$ Edition. Washington, D. C.

Dento, O.A. and Nwangburuka C.C.(2011). Heritability, genetic advance and character associationin six related characters of Solanumanguivi,Asian Journla of Agricultural Research. 5:201-207.

Diouf, D. (2011). Recent advances in cowpea (Vigna unguiculata (L). Walp). Omics Research for Genetic Improvement, African Journal of Biotechnology. 10: 2803-2810.

Duke, J.A. (1980). Vigna unguiculata (L.) Walp. In:Handbook of Legumes of World Economic Importance. Plenum Press Ltd, New York, USA. 302-316. 
Ehlers, J.D. and Hall, A.E. (1997).Cowpea (VignaunguiculataL. Walp), Field Crops Research.53: $187-204$.

FAO. (2000). The state of food insecurity in the world (SOFI) Rome. Italy: FAO-UN. www.fao. org/FOCUS/E/SOFI00/sofi001-e.htm Accessed on March 12th, 2014.

FAO.(2004). http//www.fao.stat.fao.orgAccessed of 12 $2^{\text {th }}$ March, 2014.

Geissler, P.W., Mwaniki, D.L., Thiong'o, F., Michaelsen, K.F. and Friis, H.(1998). Geophagy, iron status and anemia among primary school children in Western Kenya,Tropical Medicine and International Health. 3(7): 529-534.

Hall, A.E.,Cisse, N., Thiaw, S., Elawad, H.O.A. and Ehlers, J.D. (2003). Development of cowpea cultivars and germplasm by Bean/Cowpea CRSP,Field Crop Research. 82:103-134.

Henshaw, F.O. (2008). Varietal differences in physical characteristics and proximate composition of cowpea (Vigna unguiculata), World Journal of Agricultural Sciences. 4(3): 302-306.

Lesley, W.D. (2005). Characterization and evaluation of cowpea (Vigna unguiculata (L.) Walp.) germplasm. MSc. Thesis, University of Agricultural Science, Dharwad, Karnataka, India.

Mamiro, P.S., Mbwaga, A.M., Mamiro, D.P., Nmanri, A.W. and Kinabo, J.L. (2011).Nutritional quality and utilization of local and improved cowpea varieties in some regions in Tanzania, African Journal of Food, Agriculture, Nutrition and Development. 11(1): 4490-4506.

Manggoel, W.,Uguru, M.I., Ndam, O.N. and Dasbak, M.A. (2012). Genetic variability, correlation and path coefficient analysis of some yield component of ten cowpea [Vigna unguiculata (L.) Walp] accessions, Journal of Plant Breeding and Crop Science. 4(5): 80-86.

Mortimore, M.J., Singh, B.B., Harris, F. and Blade, S.F. (1997). Cowpea in traditional cropping systems. In:Advances in cowpea research. Singh, B. B., Mohan Raj, D. R.., Dashiell, K.E. and Jackai, L.E.N. (Eds.). Co - Publication of IITA and JIRCAS. IITA, Ibadan, Nigeria. 99-113.

Nielson, S., Ohler, T. and Mitchell, C. (1997). Cowpea leaves for human consumption: production, utilization and nutrient composition. In: Singh, S.R. and Rachie, K.O. (eds.).Cowpea researches, production and utilization. Wiley, New York. 145-162.

Nwofia, G.E., Nwanebu, M and Agbo, C.U. (2012). Variability and inter-relationship between yield and associated traits in cowpea (Vigna unguiculata L. Walp) as influenced by plant population, World Journal of Agricultural Sciences. 8(4): 396-402.

Nwosu, D.J., Olatunbosun, B.D and Adetiloye, I.S. (2013). Genetic variability, heritability and genetic advance in cowpea genotypes in two agro-ecological environments, Greener Journal of Biological Science. 3(5): 202-207.

Odedeji, J.O. and Oyeleke, W.A (2011). Proximate, physiochemical and organoleptic properties of whole and dehulled cowpea seed flour (Vigna unguiculata), Pakistan Journal of Nutrition. 10 (12): 1175-1178. 
Ogle, W.L., Witcher. W. and Barnett, O. (1997). Descriptor for southern peas of South Carolina, Bulleting of South Carolina Agricultural Experimental Station, Clemson Univeristy, Clemson: 659.

Olaleke, A.M., Olorunfemi, O. and Akintayo, T.E. (2006). Compositional evaluation of cowpea (Vigna unguiculata)and scarlet runner bean (Phaseoluscoccineus) varieties grown in Nigeria,International Journal of Food, Agriculture and Environment. 4(2): 39-43.

Olaniran, O.J. (1982). The Problems in the Measurement of Rainfall: An experiment at Ilorin, Nigeria, Weather. 37 (7): 201-204.

Omoigui, L.O., Ishiyaku. M.F., Kamara, A.Y., Alabi, S.O. and Mohammed, S.G. (2006). Genetic variability and heritability studies of some reproductive traits in cowpea [Vigna unguiculata (L.) Walp.],African Journal of Biotechnology. 5 (13):1191-1195.

Oritz, R. (1998). Cowpeas From Nigeria: a silent food revolution, Outlook on Agriculture. 27 (2): $125-128$.

Slevan, Y.A., Manivannan, N., Murugan, S., Thangavelu, P. and Ganeshan, J. (2000). Variability in cowpea (Vigna unguiculata L. Walp.), Legume Research. 23: 279-280.

Umaharan, P., Ariyanayagan, R.P. and Haque, S.O. (1997). Genetic analysis of yield and its components in vegetable cowpea [Vignaunguiculata (L.) Walp.], Euphytica. 7: 207-2013.

Vural, H. and Karasu, A. (2007). Variability studies in cowpea (Vigna unguiculata [L.] Walp.) varieties grown in Isparta, Turkey. Revista UDO Agricola. 7(1): 29-34.

Zavari, P. P., Patel, P. K., Yadavendra, J. P. and Shah, R. M. (1983). Heterosisand combining ability in cowpea,India Journal of Agricultural Science. 53: 793-796. 